\title{
In vitro pollen tube division of irradiated and non-irradiated apple pollen
}

\author{
MP Lecuyer, YX Zhang, M Tellier, Y Lespinasse
}

INRA, station d'amélioration des espèces fruitières et ornementales, centre d'Angers, 49070 Beaucouzé, France

(Received 19 November 1990; accepted 28 March 1991)

Summary - Apple pollen irradiated at 200 and 500 Gy, used to induce haploidy by parthenogenesis, was sown in liquid medium to study pollen tube germination and division. Although the irradiated pollen did germinate in vitro, fewer grains germinated more slowly relative to the control. A protocol was defined to observe pollen tube division. Although the progression of mitosis was similar to that observed with the control, the observation of the irradiated pollen showed various chromosomic abnormalities such as the presence of chromatin bridges and an uneven distribution of chromosomic material in the 2 daughter nuclei.

\section{Malus x domestica / irradiated pollen / pollen tube division / haploidy / parthenogenesis}

Résumé - Deuxième mitose pollinique du pollen irradié et non irradié chez le pommier. La recherche de plantes haplö̈des chez le pommier cultivé présente de nombreux intérêts tant pour la création variétale que pour l'étude génétique. La parthénogenèse induite in situ par du pollen irradié s'avère être la méthode donnant les meilleurs résultats. Il est donc important de développer les connaissances sur la biologie du pollen irradié afin de mieux comprendre le phénomène d'induction du développement parthénogénétique in situ. La germination et la croissance des tubes polliniques ont été étudiées in vitro, en milieu liquide. Le taux de germination est de $80 \%$ pour le pollen non irradié, de 58 et de $68 \%$ pour le pollen irradié respectivement à 200 Gy et 500 Gy (fig 1); la croissance des tubes polliniques est plus lente après irradiation (fig 2). Un protocole permettant d'observer in vitro la deuxième mitose pollinique a été défini (tableau l). Tous les stades de cette mitose ont été observés. Chez le témoin non irradié, la figure 3 illustre le stade métaphase et la figure 4, le stade anaphase. Chez le pollen irradié à 200 et 500 Gy, des anomalies chromosomiques diverses ont été observées telles que la présence de ponts de chromatine (fig 5) et une répartition inégale du matériel chromosomique dans les 2 noyaux-fils (fig 6). L'induction de la parthénogenèse ne peut en aucun cas être expliquée par l'absence de la $2^{e}$ mitose pollinique ou par la déstructuration du matériel chromosomique. Les 2 noyaux-fils contenant un nombre déséquilibré de chromosomes ne peuvent pas normalement assurer la fécondation mais pourraient stimuler la division de l'oosphère ou d'une autre cellule haploïde du sac embryonnaire et ainsi, induire le développement parthénogénétique.

Malus x domestica / pollen irradié / deuxième mitose pollinique / haploïdie / parthénogenèse 


\section{INTRODUCTION}

Research on haploid apple plants presents numerous advantages for breeding cultivars and for genetic studies (Lespinasse et al, 1982). The first apple haploid plants were isolated by in situ gynogenesis, but this resulted in insufficient yield (Lespinasse and Godicheau, 1980; Lespinasse and Chevreau, 1987). In vitro androgenesis by anther culture produced numerous embryos, but these failed to develop (Zhang et al, 1987). In vitro gynogenesis by unfertilized ovule culture only produced embryoids, which also failed to develop (Zhang and Lespinasse, 1988). The most promising results were obtained through in situ parthenogenesis induced by irradiated pollen (Zhang, 1988; Zhang et al, 1988).

Our knowledge of irradiated pollen biology has to be improved for a better unterstanding of the induction process which triggers the development of in situ parthenogenesis. Previous studies on the behaviour of irradiated pollen in vivo have demonstrated the capacity of pollen irradiated up to 1000 Gray (Gy) to germinate on the stigma, grow within the style and reach the embryo sac (Carreau, 1988). It was therefore essential to study the in vitro germination and growth of the pollen tube in both irradiated and non-irradiated pollen, and to determine the influence of irradiation on pollen tube division.

This study presents the findings obtained for in vitro pollen tube germination and growth and, for the first time, the results on pollen tube mitosis for irradiated or non-irradiated pollen.

\section{MATERIALS AND METHODS}

\section{Pollen collection and irradiation}

The pollen used was from the apple hybrid TNR31.35, which is dominant homozygous RR for the red colour of all the vegetative and reproductive organs (Lespinasse and Godicheau, 1980). Flower buds were collected just before anthesis on potted trees forced in the greenhouse. They were rubbed against fine wire mesh to separate the anthers which were dehiscent after $48 \mathrm{~h}$ at $25^{\circ} \mathrm{C}$. The pollen was then stored at $4{ }^{\circ} \mathrm{C}$ in small glass tubes $(9 \times 45 \mathrm{~mm})$ and subsequently irradiated by Cobalt 60 gamma-rays with an output of $45 \mathrm{~Gy} / \mathrm{mn}$ for total doses of 200 and $500 \mathrm{~Gy}$.

\section{Pollen tube germination and growth in vitro}

The medium used at $\mathrm{pH} 5.7$ for pollen germination contained $200 \mathrm{~g} / \mathrm{l}$ of sucrose and $20 \mathrm{mg}$ of boric acid
$\mathrm{H}_{3} \mathrm{BO}_{3}$ (Calzoni et al, 1979). Three mg of pollen were extracted with pentane and placed in a Petri dish containing moist filter paper in order to rehydrate for 30 $\mathrm{min}$ at $30^{\circ} \mathrm{C}$. After adding $2 \mathrm{ml}$ of the above medium, the pollen was incubated at $30^{\circ} \mathrm{C}$ for $2,4,6,8$ or $12 \mathrm{~h}$. For each treatment, 3 samples of 100 pollen grains were observed in order to estimate the germination rate, and 100 pollen tubes were measured to evaluate their growth.

\section{Protocol for study of pollen tube mitosis}

The cytological method on root tips proposed by Lespinasse and Salesses (1973) was used. However, the material was centrifuged between each successive step during the preparation.

The procedure was only progressively established, the success of one step allowing the following one to be tested : 1) the speed of centrifugation: 1000 and 1 $500 \mathrm{rpm}$ for 5-10 min; 2) the number of hours necessary to observe telophase: $9,12,16,18,20,22,24$ and $30 \mathrm{~h}$. This study was conducted without colchicine in the medium; 3 ) the absence or presence of magnesium at $0.02 \%$; 4) the absence or presence of colchicine at $0.02 \%$ in the germination medium to observe metaphase; 5) staining with Schiff's reagent for $1 / 2,1$ and $3 h ; 6$ ) maceration with pectinase at $2 \%$, or at $3 \%$ for $30 \mathrm{~min}, 1 \mathrm{~h}$ and $1 \mathrm{~h}$ and $30 \mathrm{~min}$.

The residue in suspension for the last time in acetic carmine gives sufficient quantities to make up dozens of preparations.

\section{RESULTS}

\section{Pollen grain germination rate and pollen tube growth}

Figure 1 shows the changes in the in vitro germination rate of irradiated (200 and 500 Gy) and non-irradiated pollen grains. For the first $2 \mathrm{~h}$, development was rapid, then regular and stabilized at $8 \mathrm{~h}$. The germination rate of non-irradiated pollen grains was $80 \%$, whereas it was $58 \%$ for the irradiated pollen grains at 200 Gy and $68 \%$ at 500 Gy.

Figure 2 shows the in vitro growth of the pollen tubes for the $12 \mathrm{~h}$ which followed their germination. Growth stopped $10 \mathrm{~h}$ after germination. The average pollen tube length was $\approx 0.9 \mathrm{~mm}$ for the control, 0.5 for 200 Gy and 0.8 for 500 Gy. The maximum length observed was $2 \mathrm{~mm}$ for the control and 500 Gy, and only $1 \mathrm{~mm}$ for $200 \mathrm{~Gy}$. At $500 \mathrm{~Gy}$, the final germination rate and the pollen tube length were greater than those obtained at 200 Gy. 


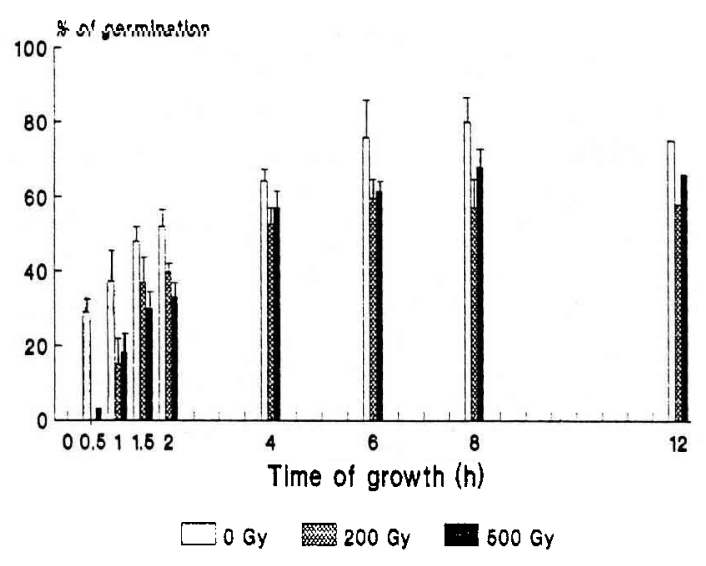

Fig 1. Germination rate of irradiated $(200,500 \mathrm{~Gy})$ and nonirradiated ( 0 Gy) pollen grains.

\section{Choice of an appropriate technique for studying pollen tube division}

Several techniques were tried; the final choice is described in table $\mathrm{I}$.

A centrifugation speed of $1000 \mathrm{rpm}$ for $10 \mathrm{~min}$ was found to be ideal, because it avoided too dense an accumulation of pollen tubes and too loose a residue, which lead to a loss of material.

The metaphase and telophase frequency was highest 12 and $24 \mathrm{~h}$ after the pollen grains had been placed in the culture medium.

A germination medium containing calcium was found to be most favourable for the observation of the chromosomes in metaphase. Calcium gave rigidity to the wall and lightened the preparations.

Colchicine at $0.02 \%$ inhibits the anaphasic process and stops division at the metaphase plate, thereby increasing metaphase frequency. For this reason, preparations were made without colchicine to observe anaphase and telophase.

In addition to acetic carmine action, $3 \mathrm{~h}$ of staining with Schiff's reagent were necessary to appropriately differentiate the small-sized apple chromosomes from the cytoplasmic background.

Pollen tube rigidity was reduced by the addition of a pectinase at $3 \%$ for at least $1 \mathrm{~h}$. In this way, chromosomes were well spread out and could be easily photographed and counted.

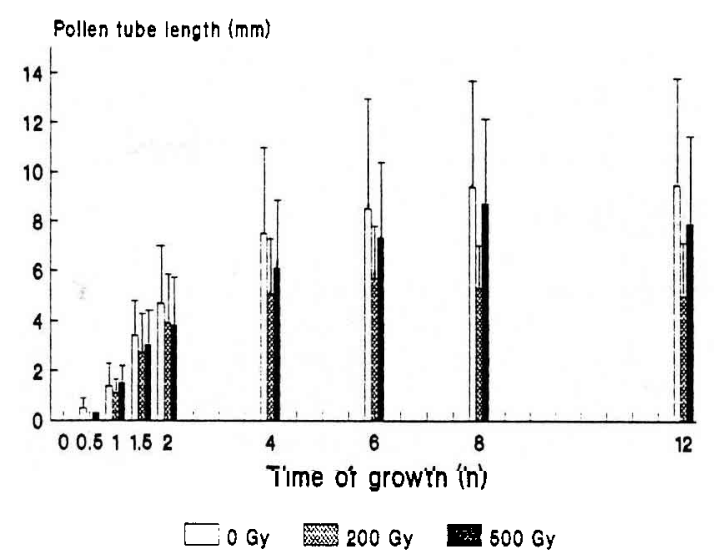

Fig 2. Growth of pollen tubes issue of irradiated $(200,500$ Gy) and non-irradiated ( $0 \mathrm{~Gy}$ ) pollen grains.

\section{Progress of pollen tube division}

\section{Control pollen}

A single nucleus migrates along the pollen tube. It reaches the first third of the pollen tube after $8 \mathrm{~h}$, the middle after $12 \mathrm{~h}$, and sometimes reaches the extremity after $18 \mathrm{~h}$. Because the pollen tube stops growing after $8 \mathrm{~h}$, the nucleus then migrates independently.

All the different mitotic stages were observed, from prophase (as early as 8-12 h), to metaphase (as early as $16 \mathrm{~h}$ ) and telophase (as early as $18 \mathrm{~h}$ ). After $18 \mathrm{~h}$, all the mitotic stages were observed simultaneously in each preparation.

Metaphase normally takes place in the second half or at the end of the pollen tube. Much prophase activity was observed, but little metaphase; a few displayed well spread-out chromosomes (fig 3) - telophase (fig 4) is more trequent.

\section{Irradiated pollen}

In irradiated samples, the pollen tube divided in much the same way as in the control pollen, but more slowly; telophase was usually observed as early as 20-24 h. Metaphase frequency was even less than usual. Various abnormalities 
Table I. Cytological technique proposed to observe apple pollen tube division.

\begin{tabular}{|c|c|c|c|c|}
\hline Treatment & & & Time & $T^{\circ} \mathrm{C}$ \\
\hline Rehydration & Pollen & & $30 \mathrm{~min}$ & $30^{\circ} \mathrm{C}$ \\
\hline Germination & $\begin{array}{l}\text { Medium } 3 \mathrm{ml} \text { : } \\
\text { Sucrose } \\
\text { Boric acid } \mathrm{H}_{3} \mathrm{BO}_{3} \\
\text { Calcium nitrate } 4 \mathrm{H}_{2} \mathrm{O} \\
\text { Colchicine * }\end{array}$ & $\begin{array}{l}2 \% \\
0.002 \% \\
0.02 \% \\
0.02 \%\end{array}$ & $16-24 h$ & $30^{\circ} \mathrm{C}$ \\
\hline Centrifugation & $1000 \mathrm{rpm}$ & & $10 \mathrm{~min}$ & Room temp \\
\hline Fixation & Acetic ethanol 3:1 & & $1-3 h$ & $5^{\circ} \mathrm{C}$ \\
\hline Storage & Acetic ethanol 3:1 & & 1 night or more & $5^{\circ} \mathrm{C}$ \\
\hline Rinsing & $\begin{array}{l}\text { Distilled water } \\
\mathrm{HCl} 1 \mathrm{~N}\end{array}$ & & $\begin{array}{l}2 \times 10 \min c \\
10 \min c\end{array}$ & $\begin{array}{l}\text { Room temp } \\
\text { Room temp }\end{array}$ \\
\hline Hydrolysis & $\mathrm{HCl} 5 \mathrm{~N}$ & & $15 \min +10 \min c$ & Room temp \\
\hline Staining & Schiff's reagent & & $3 h+10 \min ^{c}$ & Room temp \\
\hline Maceration & Rapidase $3 \%$ & & $1 \mathrm{~h}+10 \min c$ & Room temp \\
\hline Storage & \multicolumn{3}{|c|}{5 drops of aceto-carmine } & $5^{\circ} \mathrm{C}$ \\
\hline Observation & \multicolumn{4}{|c|}{$\begin{array}{l}\text { Photonic microscope-Squash } \\
\text { Search at objective } \times 40 \\
\text { Observation at objective } \times 100\end{array}$} \\
\hline
\end{tabular}

$c=$ Centrifugation. ${ }^{*}=$ Addition of colchicine only to observe metaphase.

were noted, eg chromatin bridges between the 2 nuclei at telophase (fig 5), and at this same stage, 2 uneven-sized nuclei (fig 6). Chromatin also appeared to accumulate abnormally as

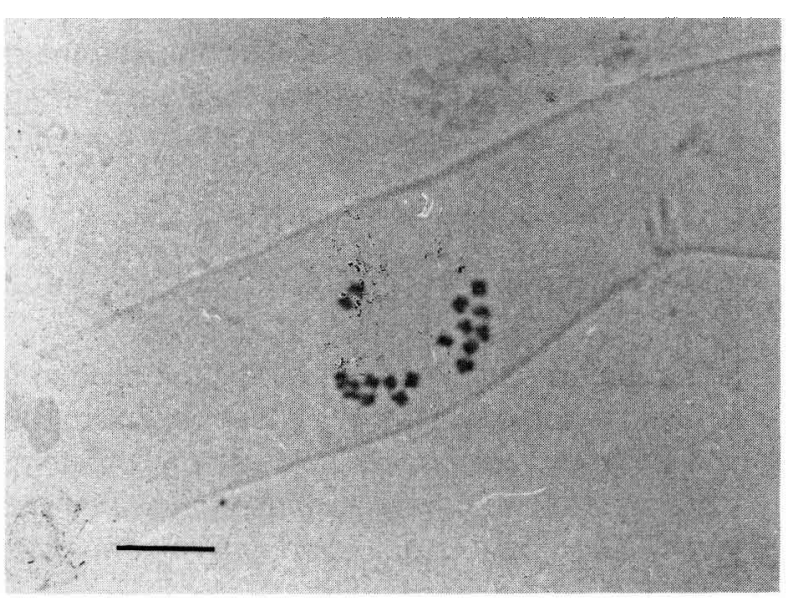

Fig 3. Normal pollen tube division from non-irradiated pollen grain. Metaphase plate showing 17 chromosomes (preparation with colchicine). Bar $=5 \mu \mathrm{m}$. "streaks". Among $\approx 20$ anaphase and telophase stages, 5 were abnormal. Lastly, no difference was found between the 2 doses of 200 and 500 Gy.

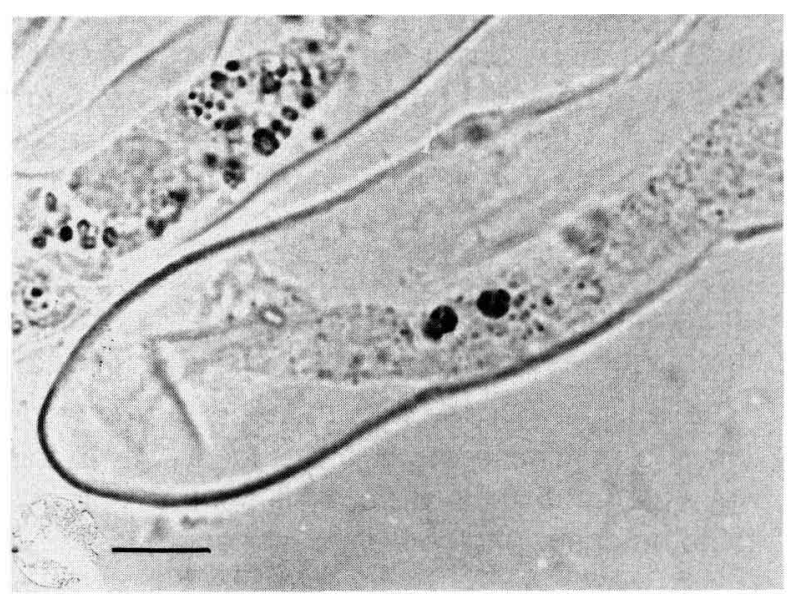

Fig 4. Normal pollen tube division from non-irradiated pollen grain. Telophase plate showing migration of the 2 daughter nuclei in pollen tube (preparation without colchicine). Bar $=5 \mu \mathrm{m}$. 


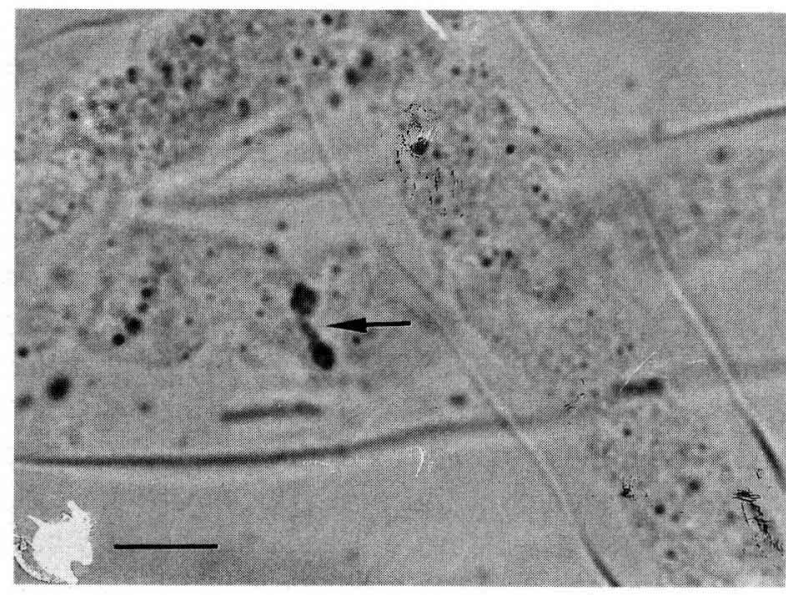

Fig 5. Abnormal pollen tube division from irradiated pollen grain at 500 Gy. Anaphase plate showing chromatin bridge (arrow). Bar $=5 \mu \mathrm{m}$.

\section{Fruit setting}

The fruit setting rates were estimated 1 month after pollination and given by the number of fruits observed for 100 pollinated flowers. The fruit setting rates obtained were $21.8 \%$ for the control, $10.2 \%$ for $200 \mathrm{~Gy}$, and $4.2 \%$ for $500 \mathrm{~Gy}$.

\section{DISCUSSION}

The results obtained, ie $\approx 80 \%$ germination for the non-irradiated pollen and $60 \%$ for the irradiated pollen, confirm the studies of Visser and Oost (1981) and Carreau (1988). However, 500 Gy irradiation seemed both to increase the rate of germination and speed up pollen tube growth compared with 200 Gy. In Douglas fir, Livingston and Stettler (1973) reported that the pollen tube lengths were positively correlated with radiation doses ranging from 40-2 560 Gy for both gamma- and X-rays. Further research (Donk et al, 1978) showed that this radiation-induced stimulation of pollen tube elongation in Douglas fir was due to an increased metabolic activity (eg, more protein synthesis) induced by higher doses of ionizing radiation. The fruit setting rates observed in our experiment decreased as the radiation dose increased and in any case they were not consistent with the fact that the growth speed and germination rate of pollen tubes were lower at 200 Gy than at $500 \mathrm{~Gy}$.

The combined action of calcium and colchicine gave better pictures of mitosis with well-aligned chromosomes, which confirms the observations made by Kwack and Kim (1966) on Tradescantia.

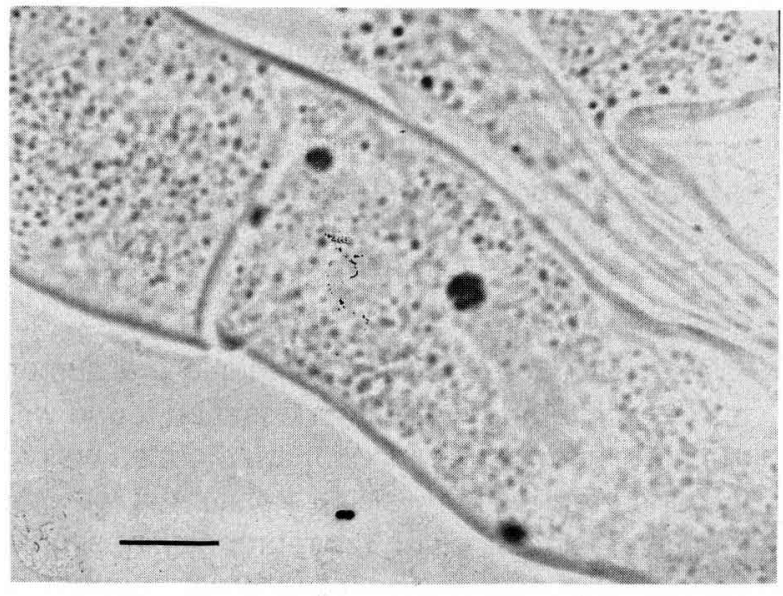

Fig 6. Abnormal pollen tube division from irradiated pollen grain at 500 Gy. Telophase plate showing the 2 nuclei of different size, often the consequence of a chromatin bridge. Bar $=5 \mu \mathrm{m}$.

The simultaneous observation of all the pollen tube division stages from $18 \mathrm{~h}$ after germination can be interpreted in 2 ways. The first hypothesis is that the triggering of division differs from 1 pollen tube to another. The second more plausible hypothesis assumes the variability of pollen tubes, either in the initiation of germination or the speed of elongation, but prophase would always begin at the same stage of pollen tube evolution.

Although numerous nuclei were observed to be in prophase on both irradiated and nonirradiated pollen, the frequency of metaphase plates was low. If the second interpretation is true, one of the reasons for this low frequency might be insufficient pollen tube elongation which is stopped in vitro. This hypothesis is supported by the findings of Kwack and Kim (1966), who observed higher metaphase frequency when pollen tube growth was more advanced. In our experiment where growth was stopped, the frequency of metaphase observed at $30 \mathrm{~h}$ was the same as at $18 \mathrm{~h}$. The method of germination developed by Te-Hsiu Ma (1967) using a thin layer of lactose agar for pollen tube culture was tried and indeed stimulated pollen tube growth and, therefore, the frequency of metaphase.

Mulcahy and Mulcahy (1983) suggested the existence of 2 phases of nutrition for binucleate pollen tubes. The first phase is autotrophic, and uses the endogenous reserves of the pollen grain; growth is slow. The second phase is heterotrophic and depends upon stylar metabolites. This second phase produces faster growth and starts with pollen tube division. It can be as- 
sumed that the in vitro growth of the binucleate apple pollen mainly takes place during the autotrophic phase. Pollen tube division would thus be initiated, but not brought to term in all the pollen tubes, which would explain the high number of nuclei in prophase and the low metaphase frequency.

The advantages of this technique are numerous. It avoids the water condensation found with the hanging-drop germination method, as well as the uncertain pollen densities observed with the thin layer lactose agar. It is reproducible, simple, permits the observation of a great number of preparations, which is not always possible with other techniques, and lastly reduces the loss of material. However, in the long term, it favours contamination and complicates the estimation of the percentage of metaphase. In any case, the calculation of a ratio is not easy, given the minute volume of the nuclei in contrast with the immense size of the pollen tubes.

Only one nucleus migrates along the pollen tube, the generative nucleus. Almost all the nuclei observed $30 \mathrm{~h}$ after germination had reached at least the prophase stage. The vegetative nucleus could not migrate but degenerated inside the pollen grain. However, Speranza et al (1982), studying the apple pollen ultrastructure, differentiated 3 zones in the growing pollen tube in vitro : the first zone, nuclear, is situated just beyong the callosis plug and contains the vegetative and generative nuclei which have both migrated within the cytoplasm. The next 2 zones, sub-apical and apical, both contain numerous organelles and large secretory vesicles. These zones were not apparent in our preparations. The single nucleus did not progress at the same rate and was not always found at the same distance from the apical zone.

Work in progress on melon has shown that pollen grains irradiated at 300 Gy have a "normal" pollen tube division (Dumas de Vaulx, personal communication). In Nicotiana (Grant et al, 1980), observation of the second pollen mitosis from pollen grains irradiated by gamma-rays at doses ranging from 250-1 000 Gy showed that irradiation caused chromatin fragmentation, lack of metaphase orientation, and failure of the generative nucleus to divide.

With the irradiated pollen in our study, the difficult separation of the 2 nuclei at anaphase sometimes caused a bridge or chromatin "streaks". This bridge could be responsible for an abnormal distribution resulting in 2 nuclei of different size. These nuclei, containing an unequal number of chromosomes, could not fertilize the egg-cell and the polar nuclei normally. Either fertilization is completely inhibited, which is probable in the case of the nuclei containing $<17$ chromosomes; or fertilization occurs, but is followed by a rejection of the male genome or by a rapid collapse of the entire zygote. As it was shown in the study of Carreau (1988) that pollen tubes from pollen grains irradiated up to 1000 Gy can penetrate into the embryo sac, it can also be suggested that the male nuclei of irradiated pollen grains, whose fertilization aptitude would be lost after gamma-radiation, could stimulate the division of egg-cell or another haploid cell, and thus induce parthenogenic development.

One of the conclusions reached is that the induction of parthenogenesis cannot be explained by the deterioration of chromosomic material or by mutations preventing pollen tube division. But one question remains unanswered: is the migration of a single reproductive nucleus in vitro similar to those in vivo?

Lastly, one of the future prospects of this technique is its use in studying the haploid genome in other species. It would be especially useful for the small-sized chromosome species where the haploid genome is difficult to characterize from haploid plant root tips or shoot apices.

\section{ACKNOWLEDGMENTS}

The authors wish to thank C Raquin, CNRS, Université d'Orsay, for pollen irradiation.

\section{REFERENCES}

Calzoni GL, Speranza A, Bagni N (1979) In vitro germination of apple pollen. Sci Hortic 10, 49-55

Carreau P (1988) Parthénogenèse induite par du pollen irradié chez le pommier (Malus $x$ domestica Borkh) : germination et croissance des tubes polliniques; évolution de l'ovule. Mémoire de DEA, université de Rennes 1

Donk JA Van Der, Livingston GK, Linskens HF, Donk M, Van Der (1978) The regulation of pollen tube growth in Douglas fir following high doses of ionizing radiation. Planta 140, 283-288

Grant JE, Pandey KK, Williams EG (1980) Pollen nuclei after ionising irradiation for egg transformation in Nicotiana. NZJ Bot 18, 339-341

Kwack BH, Kim IH (1966) An improved method for culturing Tradescantia pollen tubes for chromosomal analysis. Cytologia 32, 1-5 
Lespinasse Y, Chevreau E (1987) Progressi nel miglioramento genetico del melo: cloni autocompatibili e piante aploidi. Riv Fruttic Ortofloric 69, 25-29

Lespinasse Y, Godicheau M (1980) Création et description d'une plante haploïde de pommier (Malus pumila Mill). Ann Amélior Plant (Paris) 30, 39-44

Lespinasse Y, Salesses G (1973) Application de techniques nouvelles à l'observation des chromosomes chez les genres Malus et Pyrus. Ann Amélior Plant (Paris) 23, 381-386

Lespinasse $Y$, Godicheau M, Noiton D, Duron M (1982) L'haploïdie chez le pommier (Malus pumila Mill). In: $2 e$ Colloque sur les Recherches Fruitières, Bordeaux, 19-27

Livingston GK, Stettler RF (1973) Radiation-induced stimulation of pollen-tube elongation in Douglas fir. Radiat Bot 13, 65-72

Mulcahy GB, Mulcahy DL (1983) A comparison of pollen tube growth in bi- and tri-nucleate pollen. In: Pollen, Biology and Implications for Plant Breeding. Elsevier Biomedical, NY, 28-33

Speranza A, Calzoni GL, Cresti M, Ciampolini F (1982) Effects of gamma irradiation on in vitro germination and ultrastructure of apple pollen. Environ Exp Bot $22,339-347$
Te-Hsiu Ma (1967) Thin-layer lactose agar for pollentube culture of Tradescantia to enhance planar distribution of chromosomes. Stain Technol 42, 285-291

Visser T, Oost ET (1981) Pollen and pollination experiments. III. The viability of apple and pear pollen as affected by irradiation and storage. Euphytica $30,65-70$

Zhang $Y X$ (1988) Recherche in vitro de plantes haploïdes chez le pommier Malus $x$ domestica Borkh: androgenèse, gynogenèse, parthénogenèse induite par du pollen irradié. Thèse de Doctorat, université de Paris-Sud

Zhang $Y X$, Lespinasse $Y$ (1988) Culture in vitro d'ovules non fécondés et d'embryons prélevés 8 jours après pollinisation chez le pommier cultivé (Malus $x$ domestica Borkh). Agronomie 8, 59-64

Zhang YX, Boccon-Gibod J, Lespinasse $Y$ (1987) Obtention d'embryons de pommier (Malus $x$ domestica Borkh) après culture d'anthères. CR Acad Sci Paris 305 (série III), 443-448

Zhang YX, Lespinasse Y, Chevreau E (1988) Obtention de plantes haploïdes de pommier (Malus $\mathrm{x}$ domestica Borkh) issues de parthénogenèse induite in situ par du pollen irradié et culture in vitro des pépins immatures. CR Acad Sci Paris 307 (série III), 451-457 